\title{
Karakteristik Jamur Sagu (Volvariella sp.) Endemik Papua
}

\author{
Barahima Abbas*), Florentina Heningtyas Listyorini, dan Eko Agus Martanto \\ Fakultas Pertanian dan Teknologi Pertanian, Universitas Negeri Papua, \\ Jalan Gunung Salju Amban, Manokwari, Papua Barat 98314 \\ Diterima: 29-07-2009 Disetujui: 12-06-2010
}

\begin{abstract}
Sago mushrooms (Volvariella sp.) were known as edible mushroom which grow sporadically on decay of sago pith waste in Papua. Local people in Papua always hunting and harvesting sago mushrooms which are growing wild on decayed sago pith waste. People were enjoyed consumption of sago mushrooms. The aims of this research were to study nutrient contents of sago mushrooms as well as to distinguish the difference of morphological characters between sago mushroom and paddy straw mushroom which popular in Indonesia. Sago mushrooms were collected from Yapen regency, Papua Province and measured for their nutrient contents and morphological characteristics. The results of this research showed that morphological characteristic of sago mushroom differ from paddy straw mushroom and other edible mushroom. Nutrient contents of Sago mushroom per $100 \mathrm{grams}$ fresh weigh were follows: protein $4.00 \mathrm{~g}$, carbohydrate $2.99 \mathrm{~g}$, lipid $0.19 \mathrm{~g}$, calcium $11.53 \mathrm{mg}$, phosphorous $0.31 \mathrm{~g}$, and potassium $165.05 \mathrm{mg}$. Nutrient contents of sago mushroom were very different from that of paddy straw mushroom and others mushrooms of the genus Volvariella. Based on morphological characteristic and nutrient contents of Sago mushrooms, we suggest that sago mushrooms is a new species.
\end{abstract}

Keywords: characteristic, endemic, edible, Papua, Sago mushroom

\section{PENDAHULUAN}

Jamur pangan (edibel) berprospek cerah untuk dibudidayakan karena berharga mahal dan berpeluang untuk diekspor (Sinaga, 2001). Kebutuhan jamur edibel dunia mencapai 1.142.500 MT, yang terdiri atas pasar Eropa 402.500 MT, Asia dan Australia 3000 MT, USA 486.000 MT, Jepang dan Arab 1.000 MT, Indonesia sendiri sebesar $32.000 \mathrm{MT}$, dan negara lainnya 250.000 MT dengan harga US\$ 2,5-4 per kg (Mohi, 2007). Singapura membutuhkan 100 ton jamur edibel setiap bulan dan Malaysia membutuhkan jamur sekitar 15 ton tiap minggunya (Sadnyana, 1999).

Salah satu jamur edibel di Papua yang berpotensi untuk dibudidayakan adalah jamur sagu yang tumbuh liar di ampas sagu. Jamur sagu ini belum dikaji secara ilmiah, baik dari segi karakteristik morfologi, nutrisi, maupun aspek domestikasinya. Morfologi jamur sagu menyerupai jamur merang memiliki organ yang disebut Volvas sebagai penciri jamur dari genus Volvariella (Kuo, 2008). Sampai sekarang ini jamur sagu masih disebut Volvariella sp. karena belum pernah dilakukan identifikasi secara menyeluruh.

\footnotetext{
*Telp: +6285244696549

Email: barahimabas@yahoo.com
}

Jamur sagu (Volvariella sp.) adalah jamur pangan yang tumbuh secara sporadis di ampas sagu dan batang sagu yang sedang melapuk. Masyarakat setempat menyukai jamur sagu karena rasanya enak dan bergizi. Jamur Volvariella sp. umumnya kaya akan asam amino esensial seperti Leusin, Isoleusin, Valin, Tryptophan, Lysin, Theonin, Phenilalanin, Methinin dan Histidin (Jordan, 1993; Widiyastuti, 2005). Jamur Volvariella sp. juga kaya akan asam lemak tidak jenuh, dan dapat menurunkan kadar low density lipoprotein dalam darah (Chang, 1999).

Jamur Volvariella termasuk Divisi Basidiomycota, Kelas Agaricomycetes, Ordo Agaricales, Famili Pluteaceae, Genus Volvariella, (Moncalvo et al., 2002) speciesnya belum diketahui dengan pasti sehingga masih disebut Volvariellasp. Genus Volvariella memiliki banyak species, di antaranya yaitu: $V$. volvacea, $V$. Surecta, V. Speciosa, V. Peckii, V. Lepiotospora, V. jamaicensis, V. Hypopithys, V. Gloiocephala, dan V. Bombycina (Moncalvo et al., 2002). Berdasarkan penampakan tubuh buah jamur sagu lebih menyerupai Jamur merang ( $V$. volvacea) dibanding dengan Volvariella species lainnya. Desckripsi $V$. volvacea yaitu memiliki ukuran tudung antara $5-10 \mathrm{~cm}$, tudung berwarna keabu-abuan, panjang tungkai melebih $2 \mathrm{~cm}$, 
ukuran panjang spora 7-10,5 $\mu$ dan penyebarannya luas (Kuo, 2008).Struktur tubuh buah Jamur dari divisi Basidiomycota terdiri atas: tudung (pileus), tungkai (stipe), basidium dan spora (Herani, 2005). Spora berkecambah membentuk miselium monokaryotik kemudian mengalami perjodohan membentuk miselium dikaryotik. Miselium dikaryotik membentuk basidiocarpus (tubuh buah) yang memiliki anatomi tudung, lamella, tangkai, dan cawan (Widyastuti, 2005). Ukuran tudung bervariasi antara species yang satu dengan species yang lain, begitupula tungkai dan ukuran sporanya. Kandungan protein jamur lebih tinggi dibandingkan dengan kandungan protein pada tumbuhtumbuhan lain secara umum. Menurut Osemwegie et al., (2006) kandungan nutrisi jamur edibel yaitu protein $11,77 \%$, karbohidrat $12,63 \%$, dan serat $55 \%$.

Sampai saat ini, jamur sagu belum banyak dikaji secara ilmiah, baik dari karakteristik morfologi, nutrisi maupun dari aspek domestikasinya. Melalui penelitian ini akan diungkapkan karakteristik morfologi tubuh buah, morfologi mikroskopis jamur sagu dan nilai nutrisi yang membedakan dengan jamur merang ( $V$. volvaceae). Informasi yang didapatkan dari penelitian ini diharapkan dapat digunakan untuk budidaya jamur sagu secara komersial.

\section{BAHAN DAN METODE}

Jamur sagu yang dikarakterisasi melalui penelitian ini adalah jamur yang tumbuh alami di hutan sagu dan sagu semi budidaya. Hanya tubuh buah jamur yang tumbuh di ampas sagu yang dianggap sebagai jamur sagu dan digunakan sebagai sampel. Pengambilan sampel jamur sagu yang digunakan pada penelitian ini dilakukan di Desa Warari, Kecamatan Yapen Selatan, Kabupaten Yapen, Provinsi Papua. Peta lokasi penelitian disajikan pada Gambar 1. Lokasi penelitian yaitu kebun semi budidaya yang memiliki hamparan ampas sagu yang banyak. Kondisi alamiahnya adalah tempatnya ternaung dan hanya mendapat sedikit sinar matahari, serta kelembaban yang tinggi. Identifikasi jamur sagu yang dilakukan pada penelitian ini mengikuti metode Alexopoulus dan Mims (1979) dan Landecker (1990). Karakteristik tubuh buah jamur ditentukan berdasarkan ukuran dan karakter stipe, pileus, lamella, spora dan hifa. Kandungan nutrisi yang diukur yaitu kandungan protein, lemak, karbohidrat, dan mineral (kalsium, fosfor dan kalium). Organ stipe dan pileus diukur dengan menggunakan mistar dan mistar geser, warna lamella ditentukan berdasarkan pengamatan mata normal, ukuran dan bentuk spora ditentukan dengan menggunakan mikroskop begitu pula ukuran hifa. Sebelum diamati di bawah mikroskop, Spora dan hifa terlebih dahulu diwarnai dengan menggunakan larutan Lactofenol Blue $\left(\mathrm{CH}_{3} \mathrm{CH}(\mathrm{OH}) \mathrm{COOH}\right)$ kemudian diamati dengan menggunakan mikroskop pembesaran 400 kali dan 1000 kali. Spora yang diamati adalah spora dari tubuh buah jamur sagu yang tumbuh alami, sedang hifa yang diamati adalah hifa dari biakan murni yang sebelumnya ditumbuhkan pada media potato dextro agar (PDA) dengan menggunakan eksplan yang bersumber dari jaringan stipe. Pengujian kandungan nutrisi dilakukan oleh Laboratorium Jasa Analisis Pangan, Departemen Ilmu dan Teknologi Pangan IPB, Bogor. Penetuan kadar protein dilakukan dengan menggunakan metode Kjeldahl-mikro, kadar lemak ditentukan dengan menggunakan metode Soxhlet, kadar karbohidrat ditentukan dengan menggunakan metode by difference, kadar $\mathrm{Ca}$ dan $\mathrm{K}$ ditentukan dengan menggunakan metode AAS, dan kadar $\mathrm{P}$ ditentukan dengan menggunakan metode Spectrofotometri.

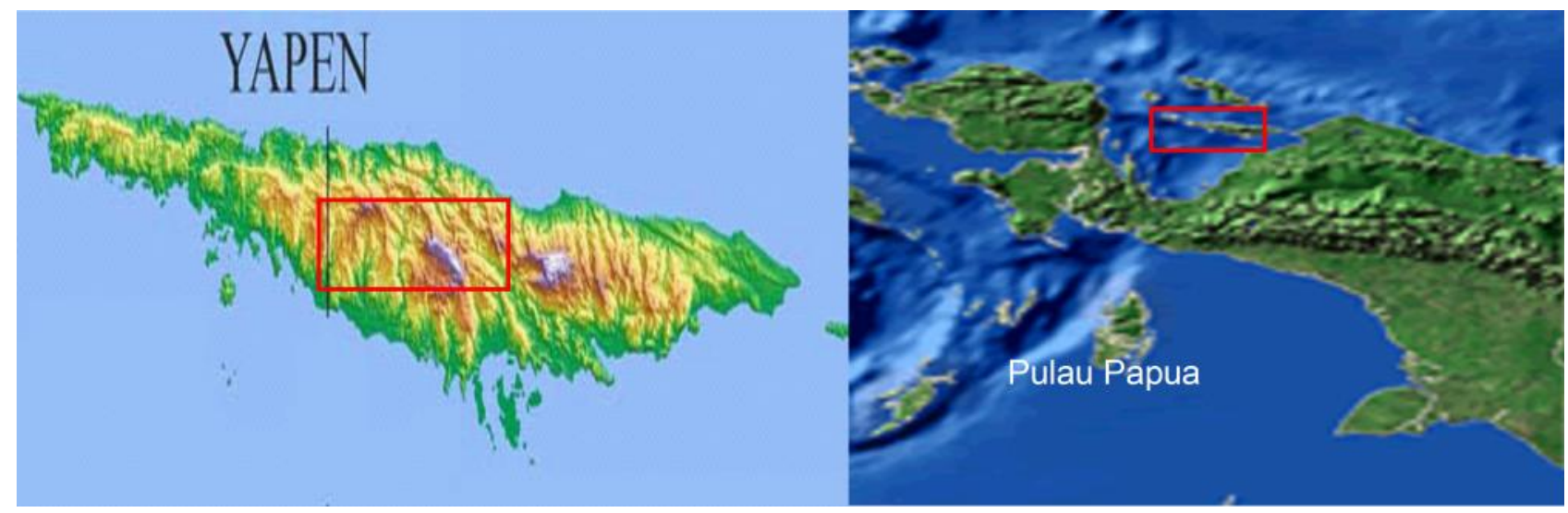

Gambar 1. Peta pulau Yapen di Papua. Lokasi pengambilan sampel Jamur sagu (kotak merah) yang digunakan pada penelitian ini 


\section{HASIL DAN PEMBAHASAN}

Observasi Jamur Sagu Endemik Papua. Saat observasi dilakukan, kami menemukan jamur sagu tumbuh di hamparan ampas sagu di hutan sagu di Distrik Yapen Selatan, Desa Warari. Bentuk dan morfologi jamur sagu yang ditemukan di Desa Warari tidak beragam. Atas dasar kesamaan bentuk dan morfologi dapat diinformasikan bahwa jamur sagu yang ada di Kabupaten Yapen hanya satu jenis yang merupakan genus dari Volvariella sp. Penampilan morfologi jamur sagu yang ditemukan di Kabupaten Yapen disajikan pada Gambar 2.

Penampilan morfologi jamur sagu dibandingkan dengan penampilan morfologi dari berbagai species dari genus Volvariella yang telah diidentifikasi dan diberi nama (Kuo, 2008) ternyata jamur sagu berbeda dengan $V$. volvacea dan V. gloiocephala (Tabel 1) serta species dari genus Volvariella lainnya, sehingga diduga jamur sagu merupakan species tersendiri di antara berbagai macam species jamur edibel dari genus Volvariella. Untuk lebih memastikan bahwa jamur sagu berbeda dengan species dari genus Volvariella masih perlu dilakukan analisis DNA dengan menggunakan berbagai macam marker molekuler.

Jamur sagu yang dijumpai di hamparan ampas sagu di lokasi penelitian terdiri atas beberapa fase pertumbuhan yaitu fase kancing, telur, elongasi, dan matang. Chang (1983) membagi menjadi enam fase

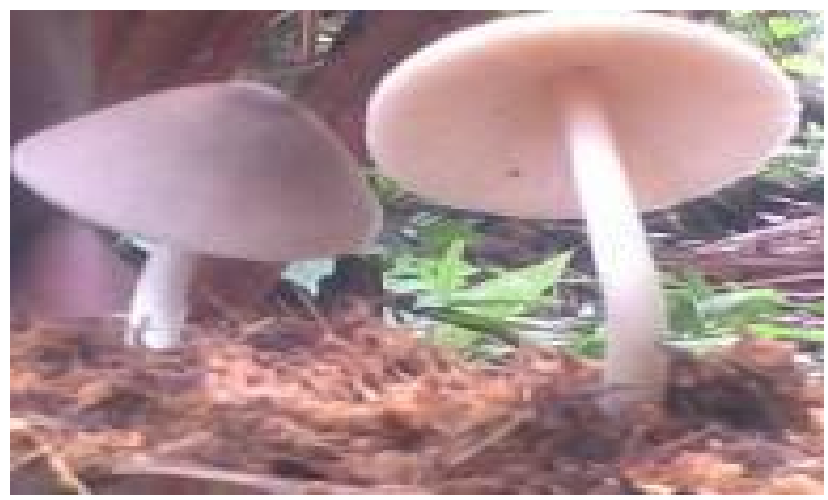

Gambar 2. Tubuh jamur sagu yang ditemukan di berbagai tempat di lapang saat dilakukan observasi perkembangan basidiocarp yaitu fase Pinhead (primordia), Tinybutton (kancing kecil), button (kancing), egg (telur), elongation (pemanjangan), dan mature (matang). Selanjutnya Li (1982) mengungkapkan bahwa fase perkembangan basidiocarp dari Devisi Basidiomycota terdiri atas empat fase yaitu fase kancing, telur, elongasi, dan maturiti. Berdasarkan pengalaman masyarakat, jamur sagu dapat dimakan dari semua stadia pertumbuhan basidiocarp yang disebutkan oleh Li (1982) karena masyarakat saat berburuh jamur sagu di hutan sagu memetik jamur sagu yang dijumpai dari semua stadia pertumbuhan untuk dijadikan lauk pauk.

Morfologi Jamur Sagu. Karakter morfologi jamur sagu yang ditemukan di Desa Warari, Kecamatan Yapen Selatan, Kabupaten Yapen disajikan pada Tabel 2 dan analisis mikroskopis spora dan hifa jamur sagu disajikan pada Tabel 3.

Adanya organ volvas pada pangkal stipe jamur sagu merupakan penciri utama bahwa jamur sagu termasuk genus Volvariella. Ciri utama jamur dari genus Volvariella yaitu adanya organ yang berbentuk selaput tipis yang menyelimuti bagian pangkal stipe dan merupakan pembungkus tubuh buah jamur saat masih muda yang disebut Volvas (Li, 1982; Landecker, 1990; \& Moncalvo et al., 2002).

Data Tabel 2 menunjukkan bahwa jamur sagu memiliki struktur tubuh buah yang cukup besar yaitu memiliki panjang stipe antara 7,5-12,5 cm dengan ratarata $10,5 \mathrm{~cm}$, diameter stipe antara $0,3-0,7 \mathrm{~cm}$ dengan rata-rata 0,44 cm, diameter pileus (tudung) antara 8-12 $\mathrm{cm}$ dengan rata-rata $10,1 \mathrm{~cm}$. Jamur edible yang memiliki kemiripan dengan jamur sagu yaitu $V$. volvacea dan V. gloiocephala. Ukuran tubuh buah jamur sagu berbeda dengan jamur merang.

Menurut Kuo (2008) V. volvacea memiliki ukuran pileus antara 5-10 cm. Selanjutnya Chang (1983) mengungkapkan bahwa panjang stipe jamur merang sekitar 5-8 cm dengan diameter 0,5-1,5 cm dan

Tabel 1. Karakteristik morfologi jamur sagu, jamur merang ( V. volvacea) dan V. gloiocephala

\begin{tabular}{|c|c|c|c|c|}
\hline No. & Karakter morfologi & Jamur sagu ${ }^{1)}$ & V. Volvacea ${ }^{2)}$ & V. gloiocephala ${ }^{3)}$ \\
\hline 1 & Panjang stipe & $7,5-12,5 \mathrm{~cm}$ & $5-8 \mathrm{~cm}$ & $5-18 \mathrm{~cm}$ \\
\hline 2 & Diameter stipe & $0,3-0,7 \mathrm{~cm}$ & $0,5-1,5 \mathrm{~cm}$ & $1,0-2,5 \mathrm{~cm}$ \\
\hline 3 & Diameter pileus & $8-12 \mathrm{~cm}$ & $5-10 \mathrm{~cm}$ & $15-14 \mathrm{~cm}$ \\
\hline 4 & Warna spora & Kuning mengkilap & Merah jambu (Pink), coklat & Merah jambu (Pink) \\
\hline 5 & Panjang spora & $5-10 \mu \mathrm{m}$ & $7,0-10,5 \mu \mathrm{m}$ & $13-18 \mu \mathrm{m}$ \\
\hline 6 & Lebar spora & $5,0-7,5 \mu \mathrm{m}$ & $4-6 \mu \mathrm{m}$ & $8-10 \mu \mathrm{m}$ \\
\hline 7 & Diameter hifa & $8-13 \mu \mathrm{m}$ & * & * \\
\hline 8 & Habitat & Ampas sagu yang melapuk & Jerami padi yang melapuk dan kompos & Gambut, kompos, serasa rumput \\
\hline
\end{tabular}

Keterangan: ${ }^{*}=$ tidak ada informasi, 1) = data primer (penelitian), 2) = data sekunder (Kuo, 2008; Chang, 1983), 3)= data sekunder (Sasata 2008) 
Tabel 2. Karakteristik morfologi jamur sagu

\begin{tabular}{cccccccc} 
No individu & Panjang stipe $(\mathrm{cm})$ & Diameter stipe $(\mathrm{cm})$ & Diameter pileus $(\mathrm{cm})$ & \multicolumn{2}{c}{ Warna pileus } & Warna \\
\cline { 5 - 6 } & & & & LD & LT & LL & lamella \\
\hline 1 & 10,0 & 0,5 & 10,0 & Hitam & Abu-abu & Kream & Merah bata \\
2 & 11,0 & 0,3 & 11,0 & Hitam & Abu-abu & Kream & Merah bata \\
3 & 9,5 & 0,4 & 9,0 & Hitam & Abu-abu & Kream & Merah bata \\
4 & 8,5 & 0,5 & 9,0 & Hitam & Abu-abu & Kream & Merah bata \\
5 & 7,5 & 0,7 & 8,0 & Hitam & Abu-abu & Kream & Merah bata \\
6 & 12,0 & 0,6 & 12,0 & Hitam & Abu-abu & Kream & Merah bata \\
7 & 12,5 & 0,5 & 11,0 & Hitam & Abu-abu & Kream & Merah bata \\
8 & 12,0 & 0,5 & 11,0 & Hitam & Abu-abu & Kream & Merah bata \\
9 & 11,0 & 0,6 & 10,0 & Hitam & Abu-abu & Kream & Merah bata \\
10 & 11,0 & 10,0 & Hitam & Abu-abu & Kream & Merah bata \\
Rata-rata & 10,5 & 0,44 & 10,1 & hitam & Abu-abu & Kream & Merah bata \\
\hline Keteram & & & & & & &
\end{tabular}

Tabel 3. Karakteristik mikroskopis spora dan hifa jamur sagu

\begin{tabular}{|c|c|c|c|c|c|c|c|}
\hline \multirow{2}{*}{ Individu } & \multicolumn{3}{|c|}{ Ukuran spora } & \multicolumn{4}{|c|}{ Hifa jamur sagu } \\
\hline & Panjang $(\mu \mathrm{m})$ & Lebar $(\mu \mathrm{m})$ & Warna & Diameter $(\mu \mathrm{m})$ & Dinding sel & Sekat & Warna \\
\hline 1 & 10,0 & 7,5 & Kuning mengkilap & 9,0 & Tebal & Bersekat & Putih \\
\hline 2 & 7,5 & 5,0 & Kuning mengkilap & 9,0 & Tebal & Bersekat & Putih \\
\hline 3 & 7,5 & 5,0 & Kuning mengkilap & 8,0 & Tebal & Bersekat & Putih \\
\hline 4 & 10,0 & 7,0 & Kuning mengkilap & 13,0 & Tebal & Bersekat & Putih \\
\hline 5 & 7,5 & 5,0 & Kuning mengkilap & 11,0 & Tebal & Bersekat & Putih \\
\hline 6 & 7,5 & 5,0 & Kuning mengkilap & 10,0 & Tebal & Bersekat & Putih \\
\hline 7 & 9,0 & 5,0 & Kuning mengkilap & 10,0 & Tebal & Bersekat & Putih \\
\hline 8 & 5,0 & 5,0 & Kuning mengkilap & 8,0 & Tebal & Bersekat & Putih \\
\hline 9 & 8,0 & 5,0 & Kuning mengkilap & 8,0 & Tebal & Bersekat & Putih \\
\hline 10 & 6,0 & 5,0 & Kuning mengkilap & 11,0 & Tebal & Bersekat & Putih \\
\hline Rata-rata & 7,8 & 5,5 & & 9,7 & & & \\
\hline
\end{tabular}
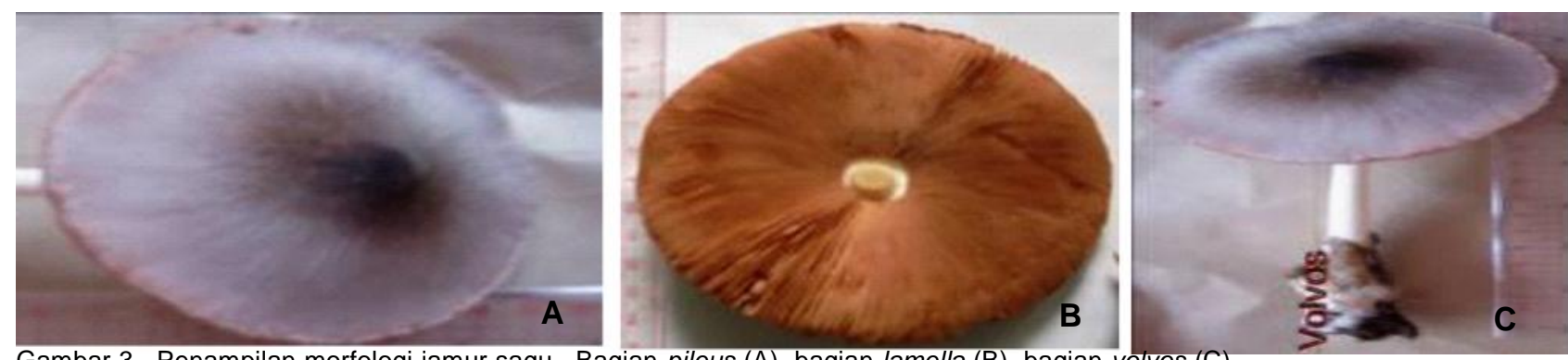

Gambar 3. Penampilan morfologi jamur sagu. Bagian pileus $(\mathrm{A})$, bagian lamella $(\mathrm{B})$, bagian volvos $(\mathrm{C})$

berwarna putih. Warna pileus jamur sagu terbagi menjadi tiga bagian yaitu lingkaran bagian dalam berwarna hitam, lingkaran bagian tengah berwarna abuabu, dan lingkaran bagian luar berwarna krem. Lamella jamur sagu berwarna merah bata menyerupai lamella Volvariella gloiocephala, tetapi ciri morfologi lainnya (diameter tudung, stipe, warna dan ukuran spora) $\mathrm{V}$. gloiocephala berbeda dengan jamur sagu sesuai dengan karakteristi yang diungkapkan oleh Sasata (2008). V. gloiocephala memiliki tudung berdiameter $5-14 \mathrm{~cm}$, panjang stipe $5-18 \mathrm{~cm}$, spora berwarna merah jambu (pink), berbentuk bulat lonjong yang panjangnya 13-18 $\mu \mathrm{m}$ dan diameternya 8-10 $\mu \mathrm{m}$ (Sasata, 2008). Penampilan morfologi bagian pileus dan lamella disajikan pada Gambar 3A dan 3B. Selain karakter yang telah diuraikan tersebut, jamur sagu juga memiliki Volvas yaitu selaput yang membungkus bagian pangkal stipe. Volvas jamur sagu berwarma krem keputihan dan menyerupai selaput (Gambar 3C).
Jamur sagu yang ditemukan di Desa Warari Kecamatan Yapen Selatan, Kabupaten Yapen memiliki bentuk spora bulat sampai bulat lonjong. Ukuran panjang spora antara 5-10 $\mu \mathrm{m}$ dengan rata-rata 7,8 $\mu \mathrm{m}$, diameter spora antara 5-7,5 $\mu \mathrm{m}$ dengan rata-rata 5,5 $\mu \mathrm{m}$, dan spora berwarna kuning mengkilap. Ukuran spora jamur sagu sedikit lebih kecil dibanding dengan spora jamur merang. Ukuran panjang spora jamur merang antara 7-10,5 $\mu \mathrm{m}$ (Kuo, 2008). Hifa jamur sagu berwarna putih dan berdiameter antara 8-11 $\mu \mathrm{m}$ dengan rata-rata $9,7 \mu \mathrm{m}$, berdinding tebal dan bersekat.

Data menunjukkan bahwa hifa jamur sagu lebih besar dibanding dengan hifa jamur merang. Diameter hifa jamur merang berukuran $6 \mu \mathrm{m}$ (Chang, 1983). Penampilan mikroskopis spora dan hifa jamur sagu disajikan pada Gambar 4. Berdasarkan karakter morfologi jamur sagu berbeda dengan karakter morfologi jamur dari genus Volvariella lainnya (Tabel 1), sehingga jamur sagu diduga merupakan species baru dari genus 

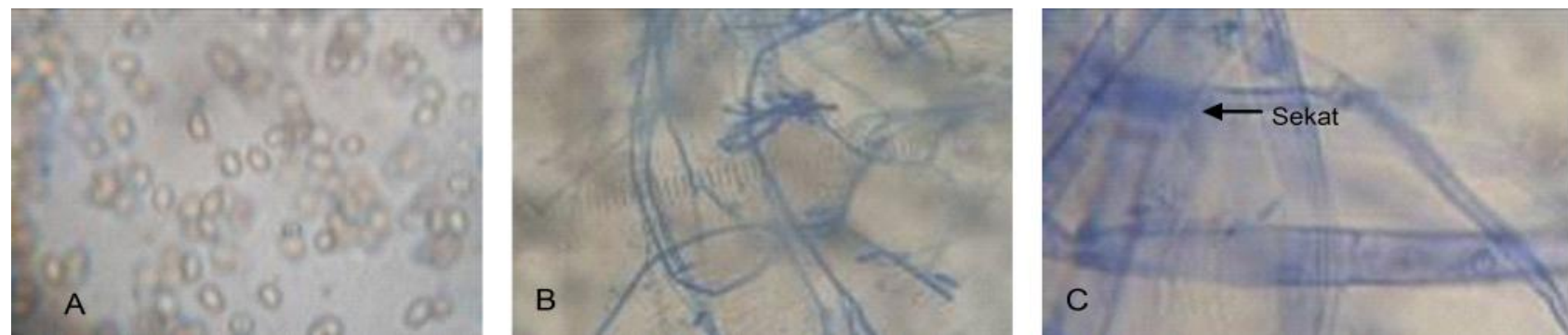

Gambar 4. Penampilan mikroskopis spora dan hifa jamur sagu pada pembesaran 400 x. Spora jamur sagu (A), hifa jamur agu (B), dan penampilan hifa bersekat dengan pembesaran $1000 \times(C)$

Tabel 4. Komposisi kandungan nutrisi jamur sagu dan jamur merang

\begin{tabular}{lcc}
\hline Nutrien/100 gram berat basah & Jamur sagu & Jamur merang \\
\cline { 2 - 3 } Protein & 4,00 gram & 2,68 gram \\
Karbohidrat & 2,99 gram & 2,60 gram \\
Lemak & 0,19 gram & $2,24 \mathrm{gram}$ \\
Kalsium & $11,53 \mathrm{mg}$ & $6,83 \mathrm{mg}$ \\
Kalium & $165,05 \mathrm{mg}$ & $402,22 \mathrm{mg}$ \\
Fosfor & $310,00 \mathrm{mg}$ & $278,46 \mathrm{mg}$ \\
Kadar abu & $300,00 \mathrm{mg}$ & $0,91 \mathrm{mg}$ \\
Kadar air & $92,52 \mathrm{gram}$ & 91,36 gram \\
\hline
\end{tabular}

Jamur sagu dianalisis di Laboratorium jasa analisis Pangan IPB, Jamur merang data sekunder dari http//www.unhas.ac.id/gdln/ dirpan/pengalengan (15 Mei 2009)

Volvariella. Meskipun demikian, masih diperlukan buktibukti lain, seperti analisis DNA untuk lebih meyakinkan bahwa jamur sagu merupakan species baru dari genus Volvariella.

Kandungan Nutrien Jamur sagu. Komposisi dan kandungan nutrisi jamur sagu sangat berbeda dengan kandungan nutrisi jamur merang dan jamur edibel lainnya dalam genus Volvariella. Nutrisi yang dikandung Jamur sagu per 100 gram berat basah yaitu sebanyak 4,00 gram protein, 2,99 gram karbohidrat, 0,19 gram lemak, $11,53 \mathrm{mg} \mathrm{Ca}, 0,31$ gram $\mathrm{P}$, dan $165,05 \mathrm{mg} \mathrm{K}$ (Tabel 4). Jamur sagu memiliki kandungan protein yang tinggi yaitu hampir dua kali lipat kandungan protein jamur merang, tetapi jamur sagu memiliki kadar lemak yang sangat rendah yaitu sekitar 20 kali lebih kecil dibanding dengan kandungan lemak jamur merang (Tabel 4). Kandungan lemak yang rendah dari jamur sagu, sehingga baik dikonsumsi oleh orang menghindari makanan yang berlemak tinggi. Bila data pada Tabel 4 dikonversi ke persen berat kering dengan berpatokan pada selisih antara kadar air dan berat segar, maka didapat persentase kandungan lemak jamur sagu sebasar $2,54 \%$, karbohidrat $39,97 \%$, dan protein $53,48 \%$. Osemwegie et al., (2006) mengungkapkan bahwa kadar nutrisi jamur merang mengandung 12,63\% karbohidrat dan $11,77 \%$ protein. Selanjutnya Widyastuti (2005) mengungkapkan bahwa kadar protein jamur merang sebesar $25,9 \%$ dan lemak $2,4 \%$ sedangkan Istimewa (2008) mengungkapkan bahwa kandungan protein jamur merang sebesar $1,8 \%$, karbohidrat sebesar $12-48 \%$, dan lemak sebesar $0,3 \%$ dari berat basah. Berdasarkan data tersebut, kandungan lemak, protein, dan karbohidrat jamur sagu lebih tinggi dibanding dengan jamur merang. Berdasarkan analisis kandungan protein beberapa jenis jamur menunjukkan bahwa kadar protein tertinggi di antara beberapa jenis jamur edibel yaitu jamur kancing (Agaricus campestris) yang memiliki kandungan protein tertinggi yaitu sebesar $33,2 \%$ dari berat kering (Widiyastuti, 2005). Jadi dapat diungkapkan bahwa jamur sagu memiliki kandungan protein paling tinggi di banding dengan jamur edibel lainnya yang telah dianalisis dan dipublikasikan.

Kandungan Kalsium (Ca) mendekati 2 kali lipat kandungan kalsium jamur merang dan kandungan Kalium (K) sekitar tiga kali lebih rendah dibanding kandungan $\mathrm{K}$ jamur merang. Untuk kandungan fosfor hampir sama dengan kandungan fosfor jamur merang, tetapi jamur sagu masih lebih tinggi dibanding dengan jamur merang (Tabel 4). Fakta data hasil analisis kandungan nutrien jamur sagu memperkuat dugaan bahwa jamur sagu berbeda dengan jamur merang dan jamur edibel lainnya.

\section{KESIMPULAN}

Karakter morfologi jamur sagu yang ditemukan tumbuh liar di ampas sagu yaitu rata-rata panjang stipe $10,5 \mathrm{~cm}$, diameter stipe 0,44, diameter pileus 10,1, panjang spora $7,8 \mu \mathrm{m}$, lebar spora $5,5 \mu \mathrm{m}$, diameter hifa 9,7 $\mu \mathrm{m}$, hifa bersekat dan berdinding sel tebal. Kadar nutrisi yang dikandung jamur sagu per 100 gram berat basah yaitu 4,00 gram protein, 2,99 gram karbohidrat, 0,19 gram lemak. Kandungan mineral per 100 jamur sagu yaitu kalsium 11,53 mg, Kalium $165,05 \mathrm{mg}$, fosfor $310,00 \mathrm{mg}$. Karakteristik morfologi dan kandungan nutrisi jamur sagu yang berbeda dengan karakteristik species jamur dari genus Volvariella lainnya, sehingga diprediksi bahwa jamur sagu merupakan species baru dari genus Volvariella. 


\section{UCAPAN TERIMA KASIH}

Ucapan terima kasih disampaikan kepada pengelola proyek Hibah Strategis Nasional dengan kontrak No. 0246.0/023-04.2/XXX/2009 yang bersumber dari DIPA Universitas Negeri Papua atas dukungan dana penelitian. Ucapan terima kasih juga disampaikan kepada Pengelola Laboratorium Jasa Analisis Pangan, IPB untuk analisis nutrisi jamur sagu, juga kepada Yosep Menai atas keterlibatannya dalam penelitian.

\section{DAFTAR PUSTAKA}

Alxopoulos, C.J. \& Mims, C.W. 1979. Introductory Mycology. $3^{\text {rd }}$ ed. New York:John Willey dan Sons.

Chang, S.T. 1983. A morfological study of Volvariella volvacea. The Chung Chi Journal. 91-103. sunzi1.lib.hku.hk/hkjo/ view/7/700083.pdf (15 Juli 2009).

Chang, S.T. 1999. Global impact of edible and medical mushroom on human welfare in the $21^{\text {st }}$ century. International journal of medical mushroom.

Herani, D. 2005. Daur hidup Basidimycota. Pustekom. http:// www.dikmenum.go. id/dataapp/e-learning/bahan/kelas3/ image/DIVISI\% BSIDIOMYCOTA.swf. (5 Maret 2009).

Istimewa. 2008. Jamur kaya nutrisi dari limbah pertanian. http:/ /www.ilmupedia.com/ akademik/29/615-jamur-kaya-nutrisidari-limbah-pertanian. htm (22 Juli 2009).

Jordan, M. 1993. Edible mushroom and other fungi. Blanford, London.
Karakteristik Jamur sagu Papua

Kuo, M. 2008. The Genus Volvariella. Retrieved from the mushroom Expert. http://www. mushroomexpert.com/ volvariella. html (17 April 2009).

Landecker, E.M. 1990. Fundamental of the Fungi. $3^{\text {rd }}$ ed. USA:Englewood Cliffs, New Jersey.

Li, G.S.F. 1982. Morfology of Volvariella volvacea. Di dalam Shuting Chang, T. H. Quimio (eds) Tropical mushrooms: biological nature and cultivation methods. books.google.com/ books?isbn=9622012647. Science (20 Juli 2009). 117-160.

Mohi, L. 2007. Jamur multi manfaat dan pasar luas. http:// ikm.depperin.go.id/Publikasi Promosi/KumpulanArtikel/ tabid/67/articleType/ArticleView/articleld/25/Jamur-MultiManfaat-Pasar-Makin-Luas.aspx (10 April 2009).

Moncalvo, J.M., Vilgalys, R., Redhead, A., Johnson, J.M., James, T.Y., Aime, M.C., Hofstetter, V., Verduin, S.J.W., Larson, E., Baroni, T.J., Thorn, R.G., Jacobsson, S., Clemencon, H. \& Miller, O.K. 2002. One hundred and seventeen clades of euagarics. Molecular Phylogenetics and Evolution 23: 357-400.

Osemwegie, O.O., Eriyamremu, G.E. \& Abdulmalik, J. 2006. A survey of macrofungi in Edo/Deltaregion of Nigeria, their morfology and uses. Global Journal of Pure and Applied Science 12(2): 149-157.

Sadnyana, I.M. 1999. Pengaruh Jenis Media dan Ketebalan Media terhadap Hasil Jamur Merang (Volvariella volvaceae). Denpasar.

Sasata, R. 2008. Volvariella gloiocephala. http://healingmushrooms.net/archives/ volvariella-gloiocephala.html (22 Juli 2009).

Sinaga. 200. Jamur Merang dan Budidayanya. Penebar Swadaya. Jakarta.

Widiyastuti, B. 2005. Budidaya Jamur Kompos. Jamur Merang dan Jamur Kancing. Penebar Swadaya. Jakarta. 